\title{
Crustacean Infestations in Some Cultured Marine Fishesin Relation Toeconomical Impact.
}

Eissa I .M, Derwa H .I. M., Maather El-Lamie M.M and Dawlat Hassanin A*

Dept. of Fish Diseases and Management, Fac. of Vet Med., Suez Canal Univ. * Veterinary Quarantine in Portsaid.

\begin{abstract}
:
This study was conducted on 525marine fishes represented as 175 of each seabass Dicentrarcus labrax,Mullet sp (Mugil cephalus and Moolgarda seheli). The clinical examination of the infested fishes showedrespiratory distress, surface swimming, bulging of opercula, sluggish movement, emaciation, severe erosion and hemorrhages of gills .Hemorrhagic areas were found on gill cover and in late stages,as well as external ulcers located in the gill filaments. Caligus and Lernanthropus species were isolated and identified from all the examined fish species. The total prevalence of the examined fish species was $55.05 \%$. The prevalence of crustaceans in D.labrax ,M.cephalus and M.seheli were 48.57, 78.28 and $38.29 \%$ respectively.The infested fishes with such crustaceans led to loss of body weight consequently, high economic losses at marketing in marine farms.
\end{abstract}

This problem was recorded and discussed.

Key words: Cultured marine fish, crustacean infestations and economic Losses.

\section{Introduction:}

Fish become the hope for overcoming protein shortage problem all over the world. Aquaculture is necessary to increase fish production (Eissaet al., 2010).The gradual increase of fish production resulted in serious pathological problems in all countries including Egypt where intensive aquaculture is practiced. Parasitic infestations represent the majority of the known infectious diseases affecting fish, they cause mortality, deformity, weight loss and different clinical abnormalities among the affected fish (Eissa, 2002). In recent years, crustacean parasitic diseases are becoming more frequent in marine aquacultureand theyare associated with high morbidity and mortality causing substantial economic losses. (Tansel and Fatih, 2012).

The present study was planned to investigate the parasitic crustaceans among some cultured marine fishes seabass Dicentrachus labrax and Mullet species Mugi lcephalus and Moolgarda seheli in relation to economic impact. 


\section{Materials\& Methods:}

\section{Fishes:}

A total number of 525 alive marine fishes were represented as 175 of each Dicentrarchus labrax,Mugil cephalus and Moolgarda seheli of different body weights were randomly collected and seasonally from some private fish farms at Deba triangle in PortSaid, Damiata Way.

\section{Aquaria:}

Fully prepared glass aquaria (100 x $50 \times 50 \mathrm{~cm}$.) were used for holding fishes. The aquaria were supplied with water from the farm; continuous aeration was maintained in each aquarium using an air pump (Elmassy, Model EM-148). Thermostatic heaters (Type CMI, Germany) were used along the course of the study in winter, early spring and late autumn to maintain the temperature at $23 \pm 1 \mathrm{C}$, while in late spring, summer and early autumn the temperature wasthe roomtemperature (22 to $32 \mathrm{C}$ ).

\section{Clinical examination:}

Clinical examination was done on live fishes and / or freshly dead ones. They were grossly examined to determineany clinical abnormalities or presence of crustacean parasites .Also, the postmortem examination was performed on all fishes according to Lucky (1977).

Parasitological examination:

The collected crustaceans from gills, skin and buccal cavity were washed withdistilled water,preserved in equal amount of
70\% alcohol-5\% glycerinin test tubes.Permanent mounts were prepared bypassage the parasite in descending grades of glycerine alcohol (70, 50 and30\%), cleared in glycerin and mounted in glycerin gelatin according to Lucky (1977)then examined microscopically. They were identified according to Badawy (1994).

\section{Detection of economic impact:}

Data used for detection of economic impact were obtained from the available records of such farms, as well as the research questionnaire designed for those that do not keep records according to El-Telbany and Atallah, (2000). The economic impact was recorded at season of marketing on 100 fish from each species. The economic analysis was done for the total costs and for the total returns. These parameters were calculated per Kilogram $(\mathrm{Kg})$ bodyweight to overcome variations in the numbers of fish used as the following:

1. Total fish yield:

Total fish yield $=$ Mean fish weight at marketing $\mathrm{X}$ number of fish.

2. Totalreturn:

Total return $(\mathrm{LE})=$ Price of $\mathrm{kg} \mathrm{X}$ Total yield.

3. Total Loss:

Total Loss $(\mathrm{LE})=$ Total return $(\mathrm{LE})$ in non-infested fish- Total return (LE) in infested fish

\section{Results}

\section{Clinical picture:}

The infested fishes from the 3 examined species showed rubbing 
the body against sides in the farms and flashing with trying to gulp atmospheric air.In M.cephalus and Moolgarda seheli, the main clinical signs were the aggregation in groups at the water inlet with severe respiratory distress. They moved rapidly in circles, with sluggish movement.Some infested fishes were suffering from emaciation, bulging of operculi and jumping out of water, this especially in M.cephalus.

Dicentrarchus.labrax

Infested haemorrhagic areas on gill cover and abdomen, ulcers on the back and bases of fins with the crustacea

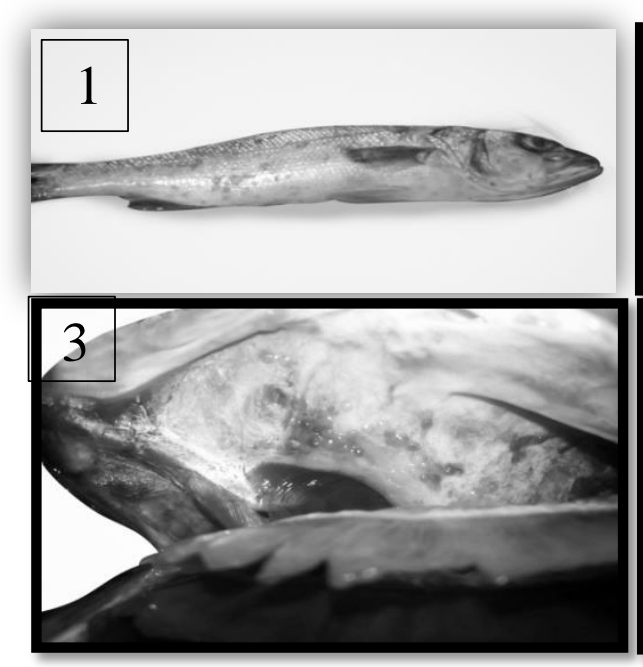

attached

to gill coverof

M.cephalus,mouth cavity of Dicentrarchus labrax and body surface of M.seheli.(Plate 1)

\section{Results of parasitological examination:}

The detected crustaceans were:

1- Caligussp:

It was isolated from body surface, gill cover and attached to mouth cavity of infested D.labrax, M.cephalus and Moolgardaseheli .

2-Lernanthropus Spp:

They were collected from gills of D.labrax, M.cephalus and Moolgardaseheli.Plate (2).

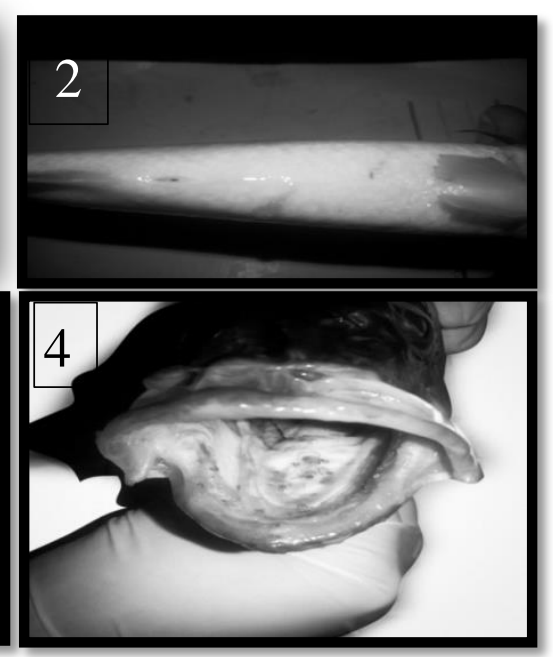

Plate(1) :A.InfestedD.labrax showing hemorrhagicareas on gill cover and abdomen ,B.Showing caligusspp attached to body surface of Moolgardaseheli.C. Showing attached caligussp to gill coverof M.cephalus, D. Showing heavey infestation of caligussp attached to mouth cavity of D.labrax. 

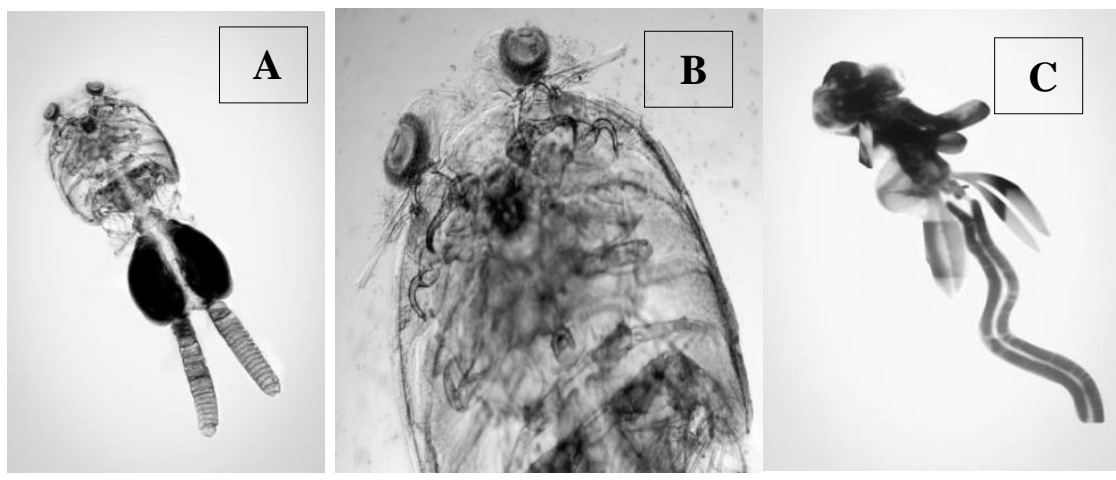

Plate(2) :.A. Showing femalecaligus sp.(Whole copepode), B. Anterior end showing first \& second maxilla and claws.C.FemaleLernanthropus sp.(whole copepode).

Table (1):Total prevalence of crustacean infestations in the different examined fish species:

\begin{tabular}{|c|c|c|c|}
\hline Fish species & No of examined fish & No. of infested fish & $\boldsymbol{\%}$ \\
\hline D.labrax & 175 & 85 & 48.57 \\
\hline M.cephalus & 175 & 137 & 78.29 \\
\hline M.seheli & 175 & 67 & 38.29 \\
\hline Total & 525 & 289 & 55.05 \\
\hline
\end{tabular}

Table (2): Seasonal prevalence among different examined fishes:

\begin{tabular}{|l|c|c|c|c|c|}
\hline Season & Autumn & Winter & Spring & Summer & Total \\
\hline D.labrax & $4(16 \%)$ & $7(28 \%)$ & $10(40 \%)$ & $64(64 \%)$ & $85(48.57 \%)$ \\
& $\mathrm{n}=25$ & $\mathrm{n}=25$ & $\mathrm{n}=25$ & $\mathrm{n}=100$ & $\mathrm{n}=175$ \\
\hline M.cephalus & $22(88 \%)$ & $11(44 \%)$ & $12(48 \%)$ & $92(92 \%)$ & $137(78.28 \%)$ \\
& $\mathrm{n}=25$ & $\mathrm{n}=25$ & $\mathrm{n}=25$ & $\mathrm{n}=100$ & $\mathrm{n}=175$ \\
\hline M.seheli & $40(40 \%)$ & $3(12 \%)$ & $10(40 \%)$ & $14(56 \%)$ & $67(38.28 \%)$ \\
& $\mathrm{n}=100$ & $\mathrm{n}=25$ & $\mathrm{n}=25$ & $\mathrm{n}=25$ & $\mathrm{n}=175$ \\
\hline Total & $66(44 \%)$ & $21(28 \%)$ & $32(42.67 \%)$ & $170(75.56 \%)$ & $289(55.05 \%)$ \\
\hline
\end{tabular}

$\mathrm{n}=$ No. of examined fish in each season 
Table (3): Economic impact in relation to crustacean infestationsin different examined fish Species

\begin{tabular}{|c|c|c|c|}
\hline Fish species & D.labrax & M.cephalus & M.seheli \\
\hline Average costs of $1 \mathrm{Kg}$ & $45 \mathrm{LE}$ & $20 \mathrm{LE}$ & $15 \mathrm{LE}$ \\
\hline $\begin{array}{l}\text { Average marketing } \\
\text { price / Kg }\end{array}$ & $65 \mathrm{LE}$ & $25 \mathrm{LE}$ & $50 \mathrm{LE}$ \\
\hline $\begin{array}{c}\text { Marketing } \\
\text { weight/fish(non } \\
\text { infested) } \\
\end{array}$ & $900 \mathrm{~g}$ & $600 \mathrm{~g}$ & $100 \mathrm{~g}$ \\
\hline Weight of infested fish & $\begin{array}{l}\text { a.light infested } \\
\text { fish }(750-850 \mathrm{~g}) \\
\text { b.heavy infested } \\
\text { fish }(550-650 \mathrm{~g}) \\
\end{array}$ & $\begin{array}{c}\text { a.light infested } \\
\text { fish }(450-550 \mathrm{~g}) \\
\text { b.heavy infested } \\
\text { fish }(350-450 \mathrm{~g}) \\
\end{array}$ & $\begin{array}{l}\text { a.light infested } \\
\text { fish }(50-100 \mathrm{~g}) \\
\text { b.heavy infested } \\
\text { fish }(<50 \mathrm{~g}) \\
\end{array}$ \\
\hline $\begin{array}{c}\text { Total number of fish } \\
\text { per feddan at marketing }\end{array}$ & 15000 & 17500 & 6000 \\
\hline Production per feddan & $\begin{array}{c}\text { a.non infested fish } \\
=13.500 \text { tons } \\
\text { b. infested } \\
\text { fish }=12.180 \text { tons }\end{array}$ & $\begin{array}{c}\text { a.non infested } \\
\text { fish }=10.500 \text { tons } \\
\text { b. infested } \\
\text { fish }=8.540 \text { tons }\end{array}$ & $\begin{array}{c}\text { a.non infested } \\
\text { fish }=600 \mathrm{Kg} \\
\text { b. infested } \\
\text { fish }=528 \mathrm{Kg}\end{array}$ \\
\hline Total losses/Tons & 1.320Tons & 1.960Tons & $72 \mathrm{Kg}$ \\
\hline Total losses/LE & 85.800LE & 49.000LE & 3.600LE \\
\hline
\end{tabular}

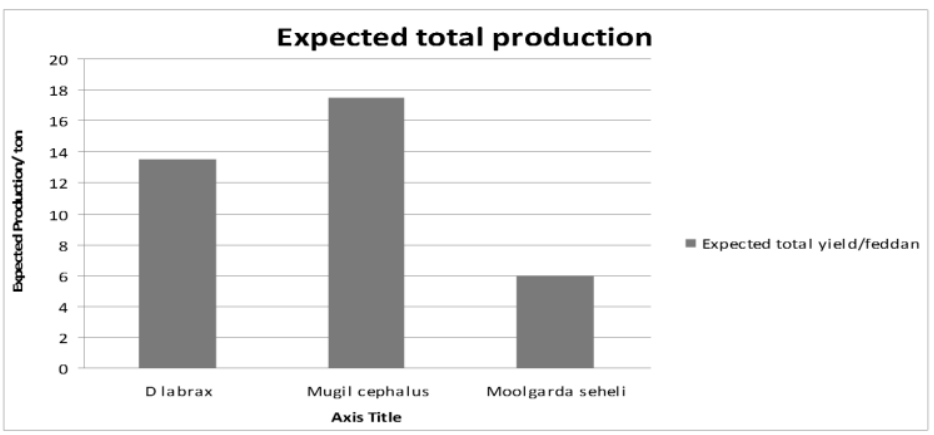

Fig (1).Expected total production in the examined fishes.

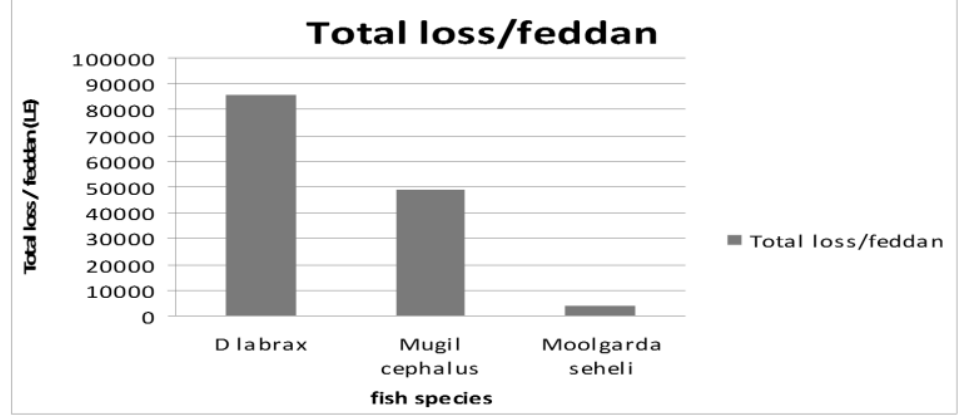

Fig (2). Total loss/ feddaninthe examined fishes.. 


\section{Discussion:}

The main clinical signs observed in the infested fisheswith parasitic crustaceans were manifested as rubbing the body against hard objects and sides of aquaria to get rid the irritation induced by the parasites. Opercula were bulging. Fish gathered at water surface with gulping the atmospheric air. These results are in agreement with those reported by Ragiaset al. (2004) and Eissa et al. (2012).

In Mugil cephalus and Moolgarda seheli the main clinical signs were the aggregation in groups at thewater inlet with severe respiratory distress and swamrapidly in circles. These signs may be attributed to massive mucoussecretions due to the irritation from contact of crustacean parasites and with their egg strings on the gill filaments which leads to gilldamage. Such results were nearly similar to that found by Eissa (2004), and Lester and Hayward (2006).

Based on the morphological and parasitological examinations, the isolated crustaceans were belonged to Caligus and Lernanthropus sp.

Lernanthropusspwas isolated from gills of D. labrax, M.cephalus and $M$. seheli .This result coincides with the findings of Tosken et al. (2008) and Eissaet al. (2012) who isolated the same genus from the same site in D.labrax.

Caligus sp isolated from gills, oral cavity and skin of D.labrax, M.cephalus and M. seheli. This result is agreement with Maran et al. (2009) and Eissa et al. (2012) that isolated the same genus from gill cavities and body surface of M.labrax.

In this work, the total prevalence of parasitic infestation in the examined fish species was $55.05 \%$.These results are lower than met by Maather El-Lamie (2007) and Eissa et al. (2012) who reported the prevalence of parasitic infestation as $70 \%$ among three marine fish species (Scomberomorous commerson, Morone labrax and Siganusrevulatus). This variation in prevalence may be due to the differences of the examined hosts anddifference in the locality from which fish samples were obtained as well as time difference.

Concerning seasonal variation of the parasitic infestation, it was clear thatthe peak was the highest in summer $75.56 \%$, followed by autumn $44 \%$ then Spring $42.67 \%$ and winter $28 \%$. This sequence nearly agreed with NoorEl-Deen et al. ( 2013) who recorded the highest infestations wereduring summer and spring and decreasedin winter and autumn.

When D.labrax, M.cephalus and Moolgarda seheli reached to harvesting weight, the results indicated that the infested fishes showed decrease in body weight in comparsion with the non-infested ones .So, there was an economic loss.InD.labrax, the total fish yield of non-infested fish per feddan was 13.500 tons, but total fish yield of 
infested fish per feddan was 12.180 tons, so the total losses were 1.320 tons, .In M.cephalus, the total fish yield of non-infested fish per feddan was 10.500 tons but total fish yield of infested fish per feddan was 8.540 tons so the total losses were 1.960 tons. In M.seheli, the total fish yield of non-infested fish per feddan was $600 \mathrm{Kg}$ but total fish yield of infested fish per feddan was $528 \mathrm{Kg}$,so the total losses were $72 \mathrm{Kg}$. These results agreed with those of Faruket al. (2004) and Thorarinsson and Powel (2006) who reported that market price and harvest weight greatly affect the economics of fish production and farm profitability. Thus, farmers are subjected to substantial economic losses as a result of crusacean fish diseases.

\section{References:}

Badawy G.A. (1994): Some studies on ectoparasites infecting marine fish in Egypt. Ph. D Thesis, Parasitology Dept. Facu.of Vet.Medicine, Zagazig Univ.

EissaI. A. M. (2002): Parasitic fish disease in Egypt. Dar El Nada El Arabia publishing, 32 Abd ElKhalikThirwatst. Cairo, Egypt ,(2): 89.

Eissa I.A.M., Gado M.S. , Laila A.M., and Noor El-DeenA.E. (2010): Field studies on the prevailing external parasitic diseases in natural maleand monosex tilapia in Kafr El-Sheikh governoratefish farms. Proc. 5th
Inter Conf. Vet. Res. Div., NRC,Cairo, Egypt, 185-192.

Eissa I. A. M., Maather El-Lamie. M. M. and Mona Zakai(2012): Studies on Crustacean Diseases of Seabass, Moronelabrax, in Suez Canal, Ismailia Governorate .Life Science J ,9(3): 515.

El-Telbany M. M. and Atallah S. T. (2000): Some cultured factors affecting the productive and economic efficiency of MugilCapito nursing in earthern pond system. $9^{\text {th }}$. Scientific Cingrees.Fac. of Vet. Med. Assiut Univ.

Faruk M.A.R,Saker M.M.R,Alam M.J and Kabir M.B.(2004): Economic Loss From Disease Rural Fresh water Aquaculture of Bangladesh .Pakistan J of Biological Science ,7(12):2086 2091.

Lester R.J.G. and Hayward C.J. (2006): Phylum Arthropoda, pp 466-565. In P.T.K., Woo.(ed.). Fish Diseases and Disorders Vol 1:Protozoan and Metazoan Infections. 2nd Ed .CAB Int, London.

Lucky Z. (1977): Methods for the diagnosis of fish diseases. American Publishing Co., Pvt. Ltd., New Delhi, Bombay Calcutta and New York.

Maather El-Lamie M. M. (2007): Studies on theparasitic diseases in some marine fishes. Ph. D.Thesis, Fac. of Vet. Med., Dept. of Fish Diseasesand Management, Suez Canal University.

MaranB.A,Venmathi, Seng L.T., Ohtsuka S. and Nagasawa $K$. 
(2009):

Records

caligus(crustacean:

Copepoda:

Calgidae) from marine fishes cultured in floating cages in Malaysia withredescription of the male of Caliguslongipedis BassettSmith, 1898. Zoological Studies, 48 (6):797-807.

Noor El-Deen A.E, Abeer, Mahmoud and Azza,H.M(2013): Field Studies of Caligus parasitic Infections among cultured Seabass (Dicentrarchuslabrax) and Mullet (Mugilcephalus)in Marine Fish farmswith Emphasis on Treatment Trials .Global Veterinaria ,11 (5): 511-520.

Ragias V., Tonis D. and Athanassopoulou F. (2004): Incidence of an intenseCaligusminimus Otto 1821, C. pagetiRussel, 1925, C. mugilis Brian, 1935 and C. apodus Brian, 1924 infection in lagoon cultured sea bass (Dicentrarchuslabrax L.) in Greece. Aquaculture, (242): 727733.

TanselT. and Fatih $P$. (2012):Ectoparasitic sea lice,Caligusminimus(Otto 1821, Copepoda: Caligida on Brawn wrasse, LabrusmerulaL., in Izmir Baye)Aegean Sea. Journal of Animal Science, 11(38): 208.

Thorarinsson $\mathbf{R}$ andPowell D.B. (2006): Effects of disease risk, vaccine efficacy, and market price on the economics of fish vaccination.Aquaculture, (256) :4249.

Toksen E, Nemli E, and Degirmenci U. (2008): The Morphology of Lernanthropuskroyeri vanBeneden, 1851(Copepoda:Lernanthropidae)

Parasitic on Sea Bass, Dicentrarchuslabrax (L.,1758), from the Aegean Sea, Turkey, ActaParasitologicaTurcica, 32 (4), 386-389.

\section{الملخص العربى}

أجريت هذه الدراسة على 175 من أسماك القاروص و 175 من أسماك البورى و 175 من أسماك

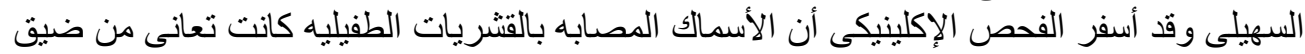

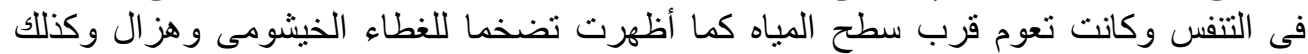

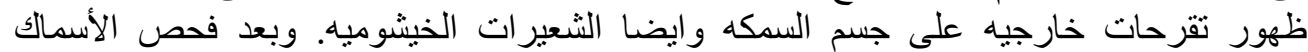

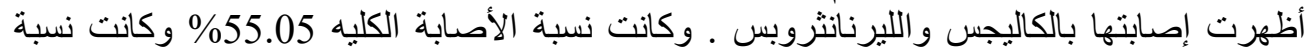

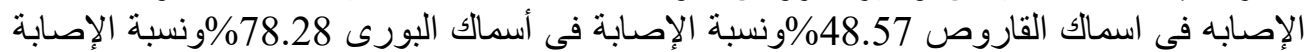

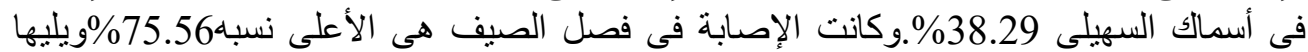

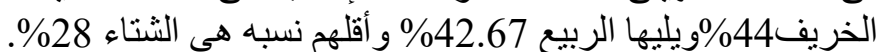

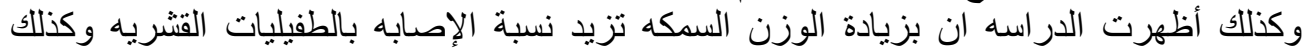

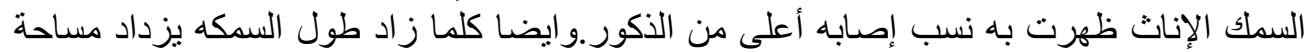

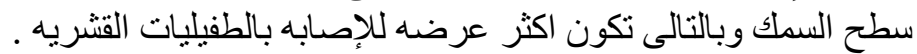

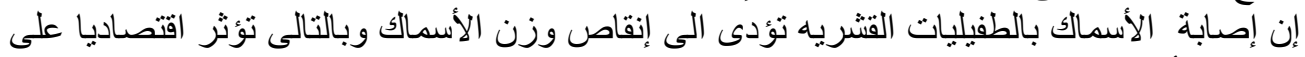
مز ارع الأسماك البحرية. 